International Journal of Physical Sciences and Engineering
Available online at http://sciencescholar.us/journal/index.php/ijpse
Vol. 3 No. 2, August 2019, pages: $12 \sim 20$
e-ISSN : 2550-6943, p-ISSN : 2550-6951
https://doi.org/10.29332/ijpse.v3n2.310

\title{
Comparative Study on NDVI with RVI for Estimated Area and Class Distribution
}

I Made Yuliara a, Ni Nyoman Ratini b, I Gde Antha Kasmawan c
Article history: Received 18 December 2018, Accepted: 30 April 2019, Published: 12 August 2019
Correspondence Author a

e-ISSN: 2550-6943, p-ISSN: 2550-6951 ๑Copyright 2019. The Author. SS Journals Published by Universidad Técnica de Manabí. This is an open-access article under the CC BY-SA 4.0 license (https://creativecommons.org/licenses/by-sa/4.0/) All rights reserved.

\section{Contents}

Abstract 12

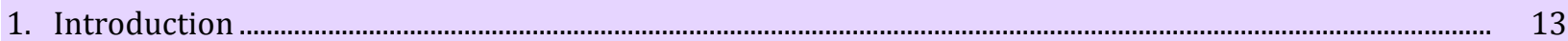

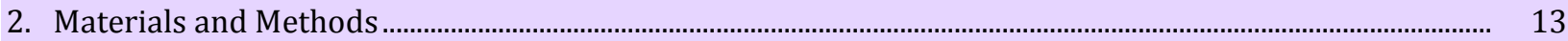

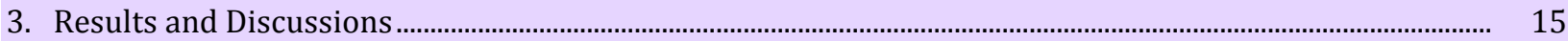

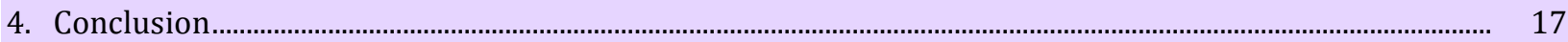

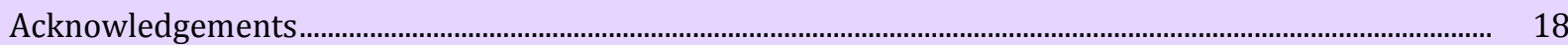

a Udayana University, Denpasar, Indonesia

b Udayana University, Denpasar, Indonesia

c Udayana University, Denpasar, Indonesia 
References

\section{Introduction}

The slow supply of information on an agricultural commodity in a broad sense requires attention. This is inseparable from the conventional methods that are still used in the data collection process, such as the clove production data in Buleleng regency, Bali. Clove production for 4 quarters of 2014 averaged $745 \mathrm{~kg} / \mathrm{ha}$ with an area of 7622.32 ha and in 2015 an average of $694 \mathrm{~kg} / \mathrm{ha}$ with an average area of 7723.91 ha (Dinas Kehutanan dan Perkebunan Pemkab Buleleng, 2014; Dinas Kehutanan dan Perkebunan Pemkab Buleleng, 2015). The application of remote sensing satellite technology has become an alternative and even the main choice for vegetation analysis studies.

Vegetation index calculation is one of the simplest types of band transformations (Rees, 2013). Some vegetation index models extracted from remote sensing satellite imagery have been widely used in various global scale vegetation studies. Remote sensing satellite technology can effectively monitor plant biomass, map land drought, Leaf Area Index (LAI), chlorophyll concentration to estimated productivity (Adams \& Gillespie, 2006; Beeri et al., 2007; Gu Wanhua et al., 2011; Xie et al., 2008). Comparative research and estimation using vegetation index in remote sensing have been carried out, both comparison between vegetation index models and index comparison of various sensors (SPOT, Landsat 7, Landsat 8) to vegetation cover (Brian et al., 2007; Dandan Xu \& Xulin Guo, 2014; GuoLin Gao \& ShiYing Wang, 2012; Hongxia Luo et al., 2014; LI Hongjun et al., 2007).

These studies analyze many index correlations with the distribution of vegetation cover, differences in sensitivity of the spectral reflectance response of vegetation and the methods used in the comparison.

Normalized Difference Vegetation Index (NDVI) and Ratio Vegetation Index (RVI) vegetation index models are the two most frequent index algorithms and are widely used in remote sensing satellite image processing. Mathematically, these two models have different shapes. The NDVI and RVI index formula involves a spectral radial two-way reflectance factor at near-infrared wavelengths (Near Infrared, usually $\lambda=0.8$ to $1.0 \mu \mathrm{m}$ ) and red wavelengths (Red, usually $\lambda=0.6$ to $0.7 \mu \mathrm{m}$ ) (Rees, 2013).

The use of Landsat 8 satellite imagery as an instrument in monitoring and mapping the utilization of natural resources and the environment is quite good results. This is inseparable from the characteristics of Landsat 8 such as having good enough spatial and temporal resolution and quite a large number of spectral resolutions, thus increasing the accuracy of data in estimating and inventorying natural resources in a large area. This study aims to determine the differences and comparison of the results of the estimated area, the distribution of clove vegetation using NDVI and RVI and to choose a vegetation index that is more suitable for clove vegetation analysis in Buleleng district, Bali.

\section{Materials and Methods}

The materials used were Landsat 8, 1 G level, May 5, 2014, for scene 1, Path 117, Row 66 and May 30, 2014, for scene 2, Path 116, Row 66. The study area is presented in Figure 1 and astronomically located in coordinates $8^{\circ} 03^{\prime} 40^{\prime \prime}-8^{\circ} 23^{\prime} 00^{\prime \prime}$ South Latitude and $114^{\circ} 25^{\prime} 55^{\prime \prime}-15^{\circ} 27^{\prime} 28^{\prime \prime}$ East Longitude.

The steps taken in this study were (1) coordinate measurements in the field (2) image data processing and analysis. At step (1), the coordinates of the sample of clove vegetation in the field are measured by selecting location points that are quite homogeneous using the Global Positioning System (GPS) Smartphone. This coordinate is used as an indicator of the position of clove vegetation at coordinates on Landsat 8 imagery.

In step (2), it begins with making the study area image by mosaicing 2 scenes of Landsat 8 imagery, then overlaid with a digital map of the study area boundaries. Reflect correction on Top Of Atmosphere (TOA) using a formula from the U.S. Geological Survey (USGS, 2019). Geometric correction refers to 9 allied control points (Ground Control Point, GCPs) performed by the nearest neighbor method. To clarify visual interpretation and highlight aspects of vegetation, stretching using the Linear with Saturation method and building a composite image with a band combination, namely Red $=$ band 6, Green = band 5 and Blue = band 4 .

Yuliara, I. M., Ratini, N. N., \& Kasmawan, I. G. A. (2019). Comparative Study on NDVI with RVI for Estimated Area and Class Distribution. International Journal of Physical Sciences and Engineering, 3(2), 12-20. 


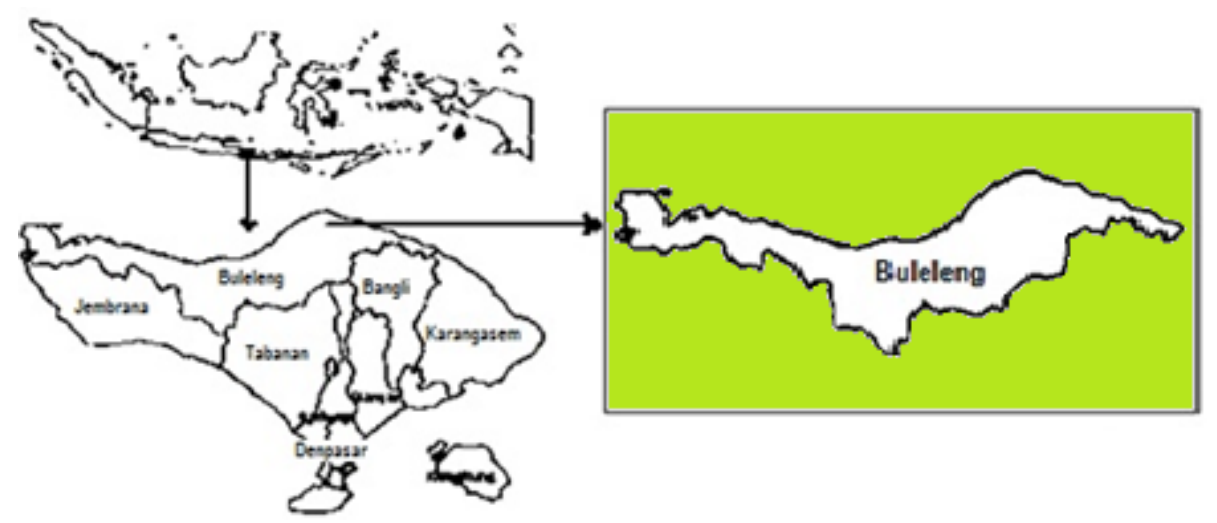

Figure 1. The regional research area of Buleleng regency, Bali

Classification of clove and no clove vegetation objects using the maximum method likelihood. The entire image data processing uses TerrSet Version 18.21 software. Two vegetation index images are built using the formula (Rees, 2013):

$$
\begin{aligned}
& N D V I=\frac{r_{i}-r_{r}}{r_{i}+r_{r}} \\
& R V I=\frac{r_{i}}{r_{r}}
\end{aligned}
$$

Where $r_{i}=$ reflectance in the NIR band (band 5)

$r_{r}=$ reflectance in the Red band (band 4)

Identification of clove vegetation index in the image is obtained by adjusting the measurement results of clove vegetation coordinates in the field with pixel coordinates in the image (Yuliara et al., 2017). Comparison and area analysis of the distribution of clove vegetation was done statistically descriptive with average area data from Plantation and Forestry Service of Buleleng regency in 2014 as a reference. More, processing and analyzing image data is presented in Figure 2.

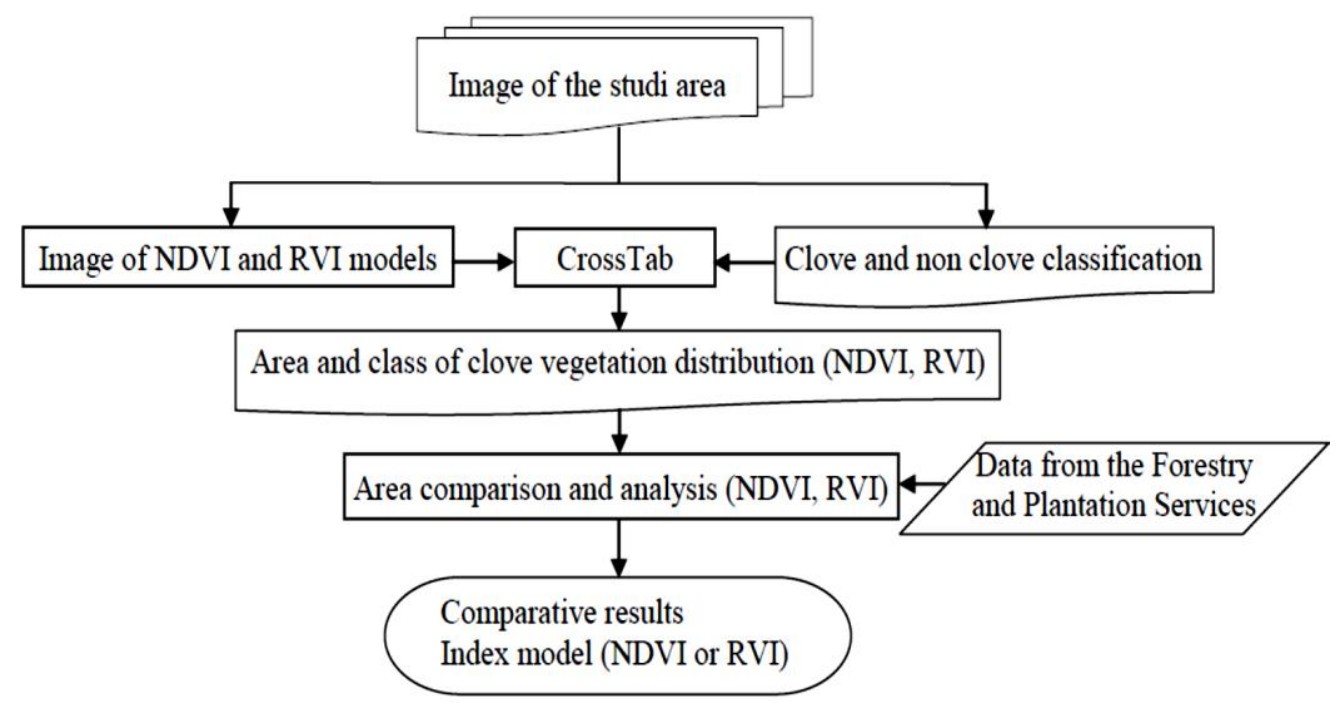

Figure 2. Research flow chart 


\section{Results and Discussions}

The image of the study area was obtained by mosaicing 2 scenes on Path 117, Row 66 and Path 116, Row 66 Landsat 8 image data for the Bali region which was then overlaid with a digital map of the boundaries of the study area. Geometric Correction and Resample using 9 Ground Control Points (GCPs) resulted in a total value of Root Mean Square (RMS) of 12.73 which is smaller than 1/2 the pixel dimension (Lillesand et al., 2015). Processing stretching contrast using the Linear with Saturation method and the formation of composite images with the composition of the RGB band $=654$.

The classification process to distinguish clove and non-clove objects using the type of hard classification and the calculation of its accuracy with the confusion matrix produces an overall accuracy of $89.16 \%$. The distribution of vegetation index values for NDVI and RVI models is calculated using the vegetation index algorithm according to Equation (1) and Equation (2). The results of the NDVI vegetation index image model with Quant palette and RVI with QualW1 palette are presented in Figure 3 and Figure 4.

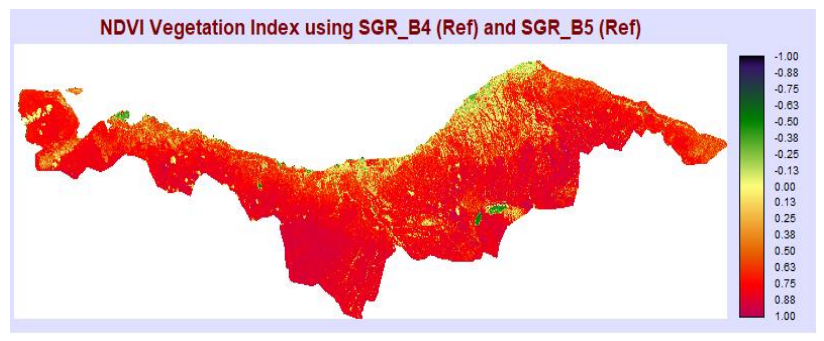

Figure 3. Distribution image of NDVI vegetation index model

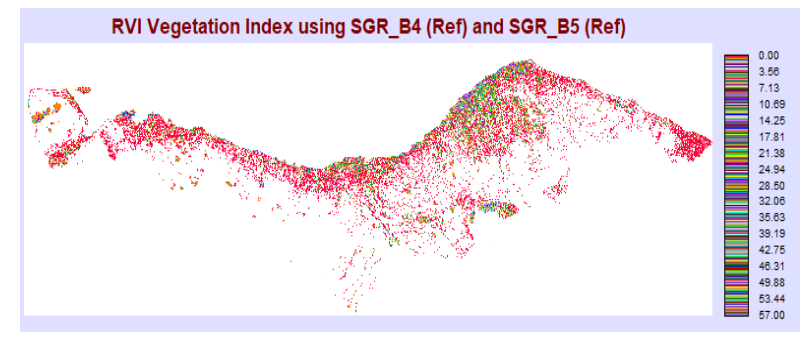

Figure 4. Distribution image of NDVI vegetation index model

The measurement results of pixel values in the study area images for NDVI and RVI vegetation index model images at 10 observation points (OP) are presented in Table 1.

Table 1

NDVI And RVI vegetation index values in the OP

\begin{tabular}{|c|c|c|c|c|}
\hline \multirow{2}{*}{ OP } & \multicolumn{2}{|c|}{ Geographical coordinates } & \multicolumn{2}{|c|}{ Vegetation index model } \\
\hline & Latitude (X) & Longitude (Y) & NDVI & RVI \\
\hline 1 & 295080 & 9092700 & 0.84810 & 0.08219 \\
\hline 2 & 295140 & 9092876 & 0.83582 & 0.08943 \\
\hline 3 & 294840 & 9093986 & 0.85714 & 0.07692 \\
\hline 4 & 295050 & 9093055 & 0.80132 & 0.11029 \\
\hline 5 & 284370 & 9083666 & 0.76543 & 0.13287 \\
\hline 6 & 295260 & 9092336 & 0.82474 & 0.09605 \\
\hline 7 & 307110 & 9098875 & 0.83226 & 0.09155 \\
\hline 8 & 306240 & 9099837 & 0.79762 & 0.11258 \\
\hline 9 & 306420 & 9099475 & 0.80800 & 0.10619 \\
\hline 10 & 307590 & 9097255 & 0.81905 & 0.09948 \\
\hline \multicolumn{3}{|c|}{ Average } & 0.10017 & 0.81895 \\
\hline
\end{tabular}

Comparison of vegetation index values of NDVI models with RVI at each OP graphically (histogram) is presented in Figure 5. The minimum and maximum values of the vegetation index model indicated as clove vegetation in the image are presented in Table 2 . The results of processing the vegetation index image where the pixels are indicated as clove vegetation from NDVI are presented in Figure 6, while for RVI are presented in Figure 7.

Yuliara, I. M., Ratini, N. N., \& Kasmawan, I. G. A. (2019). Comparative Study on NDVI with RVI for Estimated Area and Class Distribution. International Journal of Physical Sciences and Engineering, 3(2), 12-20. 


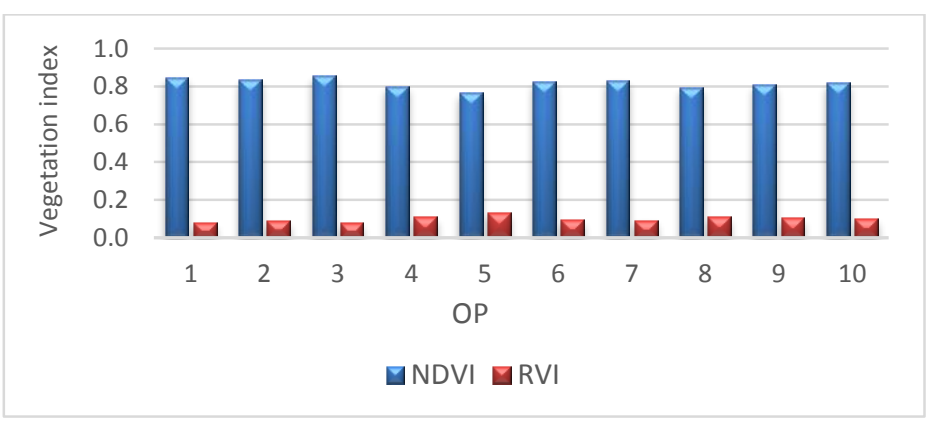

Figure 5. Histograms of NDVI and RVI index models in OP

Table 2

Minimum and maximum vegetation index values

\begin{tabular}{llc}
\hline \multirow{2}{*}{ Vegetation index model } & \multicolumn{2}{c}{ Index values } \\
\cline { 2 - 3 } & Minimum & Maximum \\
\hline NDVI & 0.76543 & 0.85714 \\
RVI & 0.07692 & 0.13287 \\
\hline
\end{tabular}

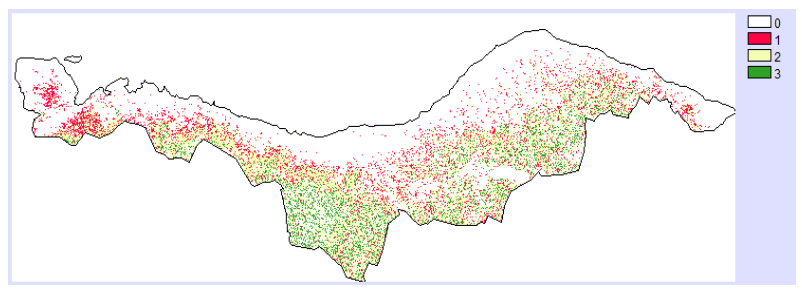

Figure 6. Class image distribution of NDVI model clove vegetation index

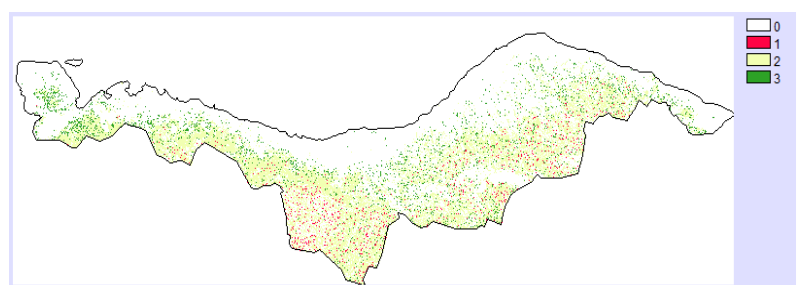

Figure 7. Class image distribution of NDVI model clove vegetation index

The results of the calculation of the accuracy-test (Overall accuracy) for the classification of clove and nonclove objects using a confusion matrix, obtained $91.64 \%$ for NDVI and RVI of $89.16 \%$. The process of identifying images to estimate the extent and class of clove vegetation distribution is done through the CROSSTAB (Cross Tabulation) module available in the TerrSet image processing module version 18.21. The results of this processing are in the form of clove vegetation distribution based on NDVI and RVI vegetation index models along with their density classes or distribution which are categorized into Rare, Medium and Dense classes. The results of statistical data processing obtained an estimate of the area of clove vegetation and the category of clove vegetation distribution are presented in Table 3.

Spatial information (map) of the distribution of clove vegetation in Buleleng regency, Bali, the NDVI vegetation index model is presented in Figure 8 and the RVI model is presented in Figure 9.

Table 3

Estimation of clove vegetation area and distribution class based on vegetation index model

\begin{tabular}{lllll}
\hline \multirow{2}{*}{ Vegetation index model } & \multirow{2}{*}{$\begin{array}{l}\text { Area estimate } \\
\text { (ha) }\end{array}$} & \multicolumn{3}{c}{ Area of distribution classes (ha) } \\
\cline { 3 - 5 } & 7852.68 & 2731.77 & Medium & Dense \\
\hline NDVI & 7669.44 & 277.92 & 4096.08 & 1024.83 \\
RVI & 183.24 & 2453.85 & 1611.45 & 1683.99 \\
Difference & 7761.06 & 1504.85 & 4901.81 & 659.16 \\
Average & & & & 1354.41 \\
\hline
\end{tabular}




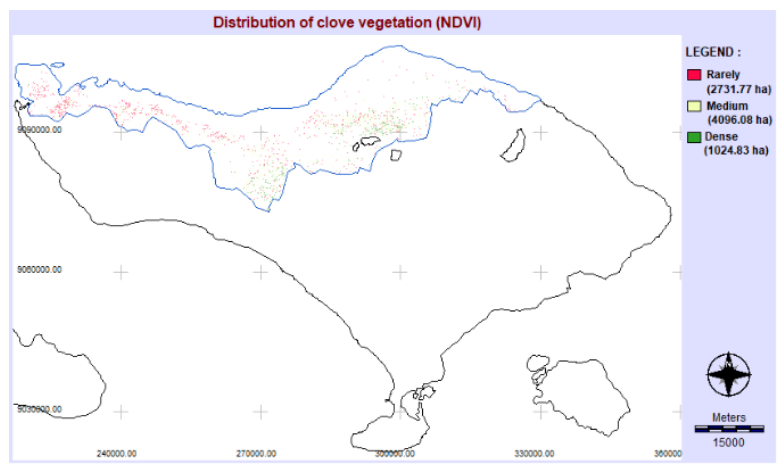

Figure 8. Distribution of clove vegetation model NDVI, Buleleng regency

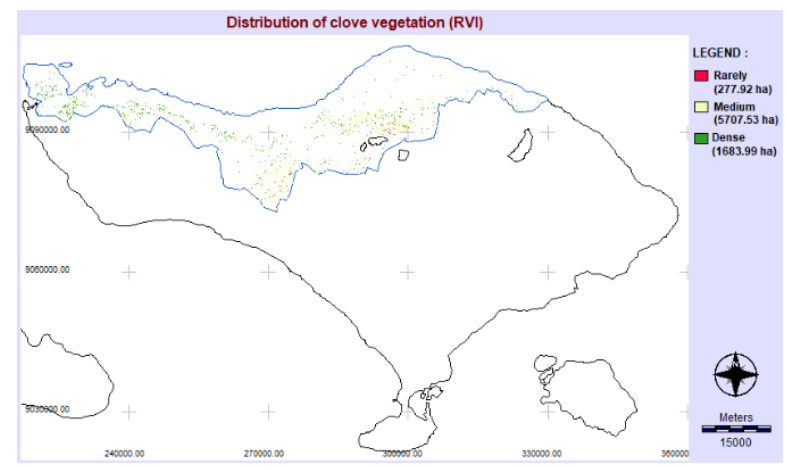

Figure 9. Distribution of clove vegetation model RVI, Buleleng regency

A complete comparison of estimated clove vegetation area based on NDVI and RVI vegetation index models with clove vegetation area data in 2014 from FPS of Buleleng regency is presented in Table 4.

Table 4

Comparison of NDVI and RVI area with FPS area Buleleng regency

\begin{tabular}{llll}
\hline Vegetation index model & Area (ha) & $\begin{array}{l}\text { Average area of FPS Buleleng } \\
\text { regency (ha) }\end{array}$ & Percentage (\%) \\
\hline NDVI & 7852,68 & 7622,32 & 97,07 \\
RVI & 7669,44 & 7622,32 & 99.39 \\
\hline
\end{tabular}

Image processing in this study generally meets the Standard Operational Procedure (Lillesand et al., 2014). In terms of quality and quantity giving good results, such as the results of geometric corrections and resample, the total value of Root Mean Square (RMS) is 12.73. This result is very good in providing certainty of the position of objects in the image and making the image already has a reference (registration) at the $50 \mathrm{~N}$ zone UTM coordinates (Mather, 2011). Processing stretching contrast using the Linear with Saturation method and the formation of composite images with the composition of the band RGB $=654$ produces better visualization compared to single-band images and visually different objects appear to be seen more clearly (Lillesand et al., 2015; Mather, 2011). The pixel values of NDVI and RVI images as presented in Table 1 represent and indicate clove vegetation objects in the OP in the field.

From Figure 5 it can be seen that, in general, the NDVI vegetation index model gives a greater vegetation index value than the RVI vegetation index model. For each OP, NDVI and RVI values appear to be opposite. That is, if an NDVI value increases, the RVI value will decrease (Purevdorj, 1998). From Table 2, it can generally be interpreted that, the minimum vegetation index value indicates the unhealthy or sparse density of clove vegetation at the location concerned, or it can be said that clove vegetation does not cover the entire soil surface. The higher the value of the vegetation index indicates the condition of clove vegetation the more healthy or fertile and dense and active in the process of photosynthesis.

\section{Conclusion}

The difference in the estimated area of the clove vegetation area between the NDVI and RVI models is 183.24 ha. The differences in the categories of sparse class areas are 2453.85 ha, Medium classes 1611.45 ha and Dense classes 659.16 ha. The results of the comparative area with FPS data are 97.07\% for the NDVI model and $99.39 \%$ for the RVI model. These results indicate that the RVI model is an index model that is more suitable for estimation of the area and class of clove vegetation distribution.

Yuliara, I. M., Ratini, N. N., \& Kasmawan, I. G. A. (2019). Comparative Study on NDVI with RVI for Estimated Area and Class Distribution. International Journal of Physical Sciences and Engineering, 3(2), 12-20. 
Acknowledgements

The authors would like to thank Udayana University for funding this research through the Leading Research Scheme from the Study Program, the year 2019. 
References

Adams, J. B., \& Gillespie, A. R. (2006). Remote sensing of landscapes with spectral images: A physical modeling approach. Cambridge University Press.

Beeri, O., Phillips, R., Hendrickson, J., Frank, A. B., \& Kronberg, S. (2007). Estimating forage quantity and quality using aerial hyperspectral imagery for northern mixed-grass prairie. Remote Sensing of Environment, 110(2), 216-225. https://doi.org/10.1016/j.rse.2007.02.027

Dinas Kehutanan dan Perkebunan Pemkab Buleleng. (2014). Laporan Triwulan Luas Areal dan Produksi Komoditas Perkebunan Kabupaten Buleleng Tahun 2014.

Dinas Kehutanan dan Perkebunan Pemkab Buleleng. (2015). Laporan Triwulan Luas Areal dan Produksi Komoditas Perkebunan Kabupaten Buleleng Tahun 2015.

Gao, G., \& Wang, S. (2012, June). Compare Analysis of Vegetation Cover Change in Jianyang City Based on RVI and NDVI. In 2012 2nd International Conference on Remote Sensing, Environment and Transportation Engineering (pp. 1-4). IEEE. https://doi.org/10.1109/RSETE.2012.6260516

Gu, W., Ma, W., Zhou, L., Tang, L., \& Huai, H. (2011). RS estimation of chlorophyll-a concentration based on RVI regionalization during algae blooming period in Dianshan Lake. Research of Environmental Sciences, 24(6), 666672.

Li, H., Zheng, L., Lei, Y., LI, C., \& ZHOU, K. (2007). Comparison of NDVI and EVI based on EOS/MODIS data. Progress in geography, 1 .

Lillesand, T., Kiefer, R. W., \& Chipman, J. (2015). Remote sensing and image interpretation. John Wiley \& Sons.

Luo, H., Fang, J., Li, H., Wang, L., Dai, S., \& Chen, S. (2014, August). Comparison and analysis NDVI and RVI changes before and after typhoon in Hainan based on HJ-1CCD satellite images. In 2014 The Third International Conference on Agro-Geoinformatics (pp. 1-4). IEEE. https://doi.org/10.1109/AgroGeoinformatics.2014.6910615

Mather, P. M., \& Koch, M. (2011). Computer processing of remotely-sensed images: an introduction. John Wiley \& Sons.

Purevdorj, T. S., Tateishi, R., Ishiyama, T., \& Honda, Y. (1998). Relationships between percent vegetation cover and vegetation indices. International journal of remote sensing, 19(18), 3519-3535. https://doi.org/10.1080/014311698213795

Rees, W. G. (2013). Physical principles of remote sensing. Cambridge University Press.

USGS. (2019). Using the USGS Landsat Level-1 Data Product. https://www.usgs.gov/landresources/nli/landsat/using-usgs-landsat-level-1-data-product

Wardlow, B. D., Egbert, S. L., \& Kastens, J. H. (2007). Analysis of time-series MODIS 250 m vegetation index data for crop classification in the US Central Great Plains. Remote Sensing of Environment, 108(3), $290-310$. https://doi.org/10.1016/j.rse.2006.11.021

Xie, Y., Sha, Z., \& Yu, M. (2008). Remote sensing imagery in vegetation mapping: a review. Journal of plant ecology, 1(1), 9-23. https://doi.org/10.1093/jpe/rtm005

$\mathrm{Xu}$, D., \& Guo, X. (2014). Compare NDVI extracted from Landsat 8 imagery with that from Landsat 7 imagery. American Journal of Remote Sensing, 2(2), 10-14.

Yuliara, I. M., Sutapa, G. N., \& Kasmawan, G. A. (2018). Development and optimization of the ratio vegetation index on the visible and infrared spectrum. International journal of physical sciences and engineering, 2(2), 101110. https://doi.org/10.29332/ijpse.v2n2.172

Yuliara, I. M., Ratini, N. N., \& Kasmawan, I. G. A. (2019). Comparative Study on NDVI with RVI for Estimated Area and Class Distribution. International Journal of Physical Sciences and Engineering, 3(2), 12-20. 


\section{Biography of Authors}

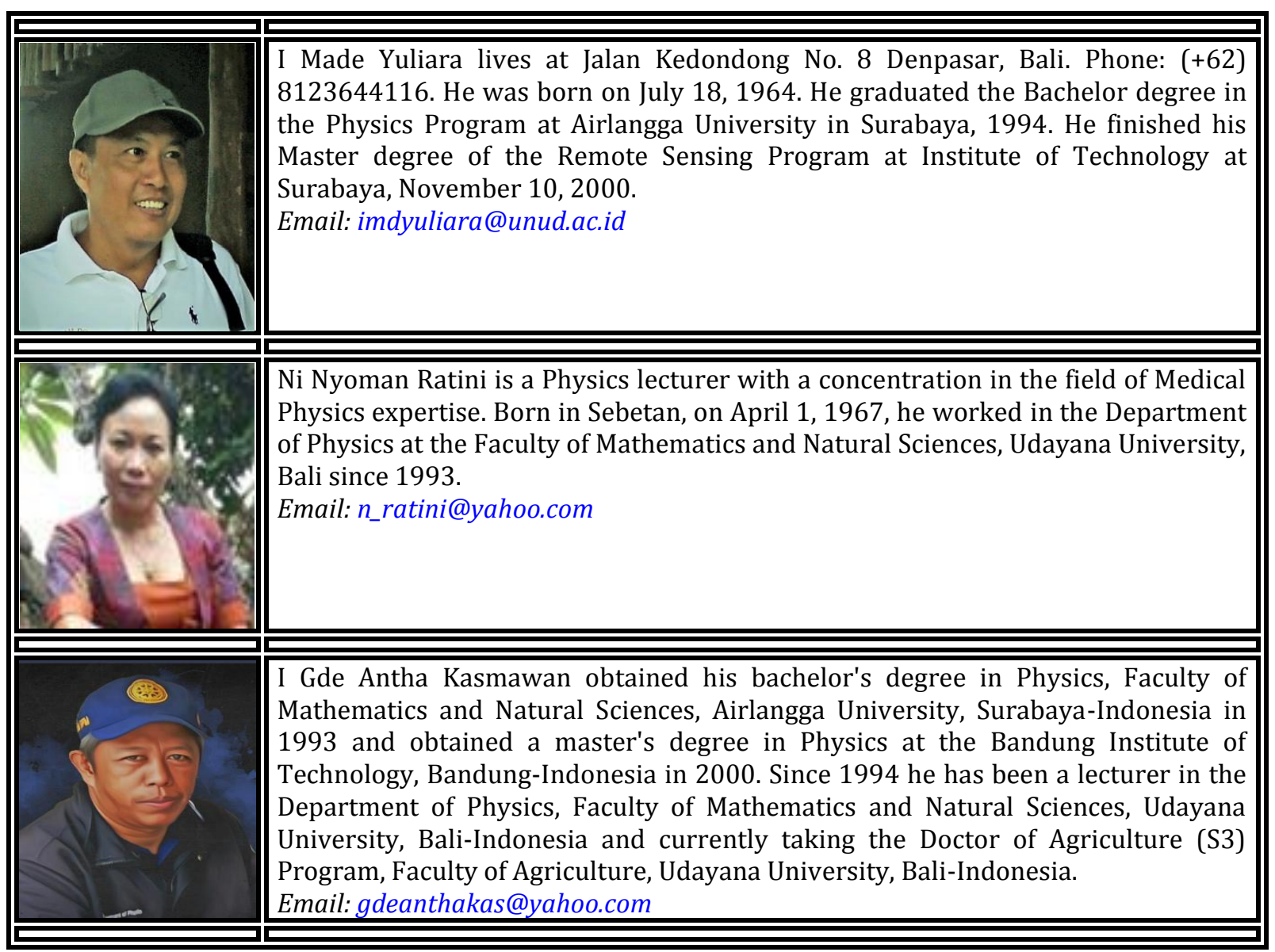

